\title{
KEEFEKTIFAN STRATEGI PENGAJARAN MEMBACA RESIPROKAL DAN STRATEGI BERPIKIR TERARAH DALAM PEMBELAJARAN PEMAHAMAN BACAAN PADA SISWA SMP
}

\author{
Titis Kusumaningrum Witdaryadi Putri \\ SMA 1 Kebumen \\ email: titiskusuma23@gmail.com
}

\begin{abstract}
ABSTRAK
Penelitian ini bertujuan untuk mengetahui (1) keefektifan strategi pengajaran membaca resiprokal dan strategi berpikir terarah dan (2) strategi yang paling efektif di antara strategi pengajaran membaca resiprokal, strategi berpikir terarah, dan strategi konvensional. Selain itu, penelitian ini juga bertujuan untuk mendeskripsikan (3) kendala yang dihadapi guru dalam menerapkan strategi pengajaran membaca resiprokal dan strategi berpikir terarah beserta solusi untuk mengatasi kendala. Penelitian ini merupakan metode penelitian kombinasi dengan model penelitian sequential explanatory design. Teknik pengambilan sampel menggunakan simple random sampling dan cluster random sampling. Teknik pengumpulan data yang digunakan adalah tes, wawancara, dan observasi. Teknik analisis data yang digunakan adalah uji analisis varians satu jalan yang dilanjutkan uji scheffe dengan taraf kesalahan 0,05 . Penelitian kualitatif yang diterapkan adalah penelitian kualitatif deskriptif. Hasil penelitian menunjukkan sebagai berikut. (1) Strategi pengajaran membaca resiprokal lebih efektif daripada strategi konvensional; strategi berpikir terarah lebih efektif daripada strategi konvensional. (2) Strategi pengajaran membaca resiprokal paling efektif daripada strategi berpikir terarah dan strategi konvensional. (3) Kendala dalam penerapan strategi pengajaran membaca resiprokal antara lain beberapa siswa masih kesulitan dalam membuat prediksi, pertanyaan, mengklarifikasi, dan meringkas; kendala dalam penerapan strategi berpikir terarah antara lain beberapa siswa masih kesulitan dalam membuat prediksi, kesalahan teknis dalam membaca, dan membuktikan prediksi. Guru mengatasi kendala tersebut dengan memberikan motivasi, contoh, dan arahan kepada siswa.
\end{abstract}

Kata Kunci: strategi pengajaran membaca resiprokal, strategi berpikir terarah, pemahaman bacaan

\section{THE EFFECTIVENESS OF THE RECIPROCAL TEACHING AND DRTA STRATEGIES IN THE LEARNING OF READING COMPREHENSION FOR STUDENTS OF JHSS}

\begin{abstract}
This study aimed to: 1) find out the effectiveness of the reciprocal teaching and DRTA strategies, (2) find out which strategy was the most effective among the reciprocal teaching, DRTA, and conventional strategies. In addition, this study aimed to (3) describe the constraints that the teacher faces in the application of the reciprocal teaching and DRTA strategies and the solutions to the constraints. This was a mixed methods study using the sequential explanatory design. The sample was selected by means of the simple random sampling technique and the cluster random sampling technique. The data were collected through tests, interviews, and observations. The data analysis technique was the one-way analysis of variance continued by the scheffe test at a significance level of 0.05 . The qualitative study was the descriptive qualitative study. The results of the study are as follows. (1) The reciprocal teaching strategy is more effective than the conventional strategy; the DRTA strategy is more effective than the conventional strategy. (2) The reciprocal
\end{abstract}


teaching strategy is the most effective than the DRTA strategy and conventional strategy. (3) The constraints in the application of the reciprocal teaching strategy are, among others, that the students still find it difficult to make predictions about questions, clarification, and summary; constraints in the application of the DRTA strategy are, among others, that the students still find it difficult to make predictions, there are technical mistakes in reading, and they find it difficult to prove predictions. The teacher deals with the constraints by giving motivation, examples, and directions to the students.

Keywords: reciprocal teaching strategy, DRTA strategy, reading comprehension

\section{PENDAHULUAN}

Kegiatan membaca merupakan salah satu aktivitas penting dan tidak dapat dipisahkan dalam dunia pendidikan. Hal ini dikarenakan sebagian besar pengetahuan disampaikan dalam bahasa tulis. Kemampuan membaca seorang siswa akan berpengaruh pada keluasan pandangannya mengenai berbagai hal. Smith (1988: 176) menyatakan bahwa siswa yang lebih banyak membaca akan memiliki kosakata yang lebih luas, pemahaman yang lebih baik, dan secara umum memiliki tingkat akademik yang lebih baik. Dengan kata lain, membaca dapat membuat siswa lebih pandai karena siswa terlatih untuk berpikir kritis.

Berdasarkan Kurikulum Tingkat Satuan Pendidikan (KTSP) yang berlaku di SMP, membaca merupakan salah satu kemampuan yang harus dikuasai dalam mata pelajaran bahasa Indonesia. Oleh karena itu, siswa harus mencapai ketuntasan nilai pada standar kompetensi tersebut. Harris \& Sipay (1985: 1-2) menyatakan bahwa siswa yang tidak memiliki kemampuan membaca dengan cukup sebagian besar harus mengulang di kelas. Jika siswa tersebut naik kelas, maka hampir dipastikan akan gagal sebelum kelulusan. Pendapat tersebut tidak berlebihan karena kemampuan membaca merupakan kemampuan dasar bagi siswa dalam memahami berbagai ilmu yang sebagian besar disampaikan dalam bahasa tulis.

Selaras dengan pendapat tersebut, Nurgiyantoro (2011: 368) menyatakan bahwa keberhasilan studi seseorang akan sangat ditentukan oleh kemampuan dan kemauan membacanya. Kemampuan membaca yang dimaksud adalah kemampuan pembaca dalam hal memahami apa yang dituturkan pihak lain melalui sarana tulisan. Pemahaman merupakan suatu hal yang penting dalam kegiatan membaca. Seseorang yang memiliki pemahaman yang baik, akan lebih mudah dalam menangkap dan memaknai informasi dari berbagai macam sumber tertulis. Pemahaman membaca yang dimiliki siswa dapat memberikan kontribusi yang besar bagi siswa dalam mencapai prestasi belajar yang dicita-citakan.

Pada kenyataannya, kemampuan membaca siswa masih belum sesuai dengan harapan. Hal ini terlihat dari hasil riset Programme for International Student Assement (PISA) pada tahun 2012 (OECD, 2013: 5) yang menempatkan posisi siswa Indonesia ke-64 dari 65 negara yang berpartisipasi dalam tes. PISA merupakan sebuah studi internasional yang mengukur literasi membaca, matematika, dan sains siswa berusia 15 tahun. Rata-rata skor skor membaca siswa Indonesia 396, jauh di bawah rata-rata skor OECD, yakni 496.

Rendahnya kemampuan membaca siswa dapat diakibatkan oleh beberapa faktor. Salah satunya, yakni guru kurang menguasai berbagai strategi dalam pembelajaran membaca. Hal tersebut yang pada akhirnya membuat siswa tidak antusias dalam mengikuti pembelajaran membaca di kelas. Ada berbagai strategi yang dapat diterapkan sebagai alternatif dalam pembelajaran pemahaman bacaan. Wiesendanger (2001: 78-194) mengemukakan bahwa ada beberapa strategi yang dapat digunakan dalam pembelajaran membaca pemahaman, yakni 1 . Strategi Berpikir Terarah, 2. Prosedur Pengajaran Terpimpin, 3. KWL-Plus, 4. Strategi QAR, dan 5. Strategi Pengajaran Membaca Resiprokal. Strategi-strategi tersebut memiliki keunggulan masing-masing dalam pembelajaran pemaha- 
man bacaan, sehingga guru harus memahami langkah-langkah dalam strategi tersebut agar dapat menerapkan dengan tepat.

Dalam penelitian ini, akan diteliti keefektifan strategi pengajaran membaca resiprokal dan strategi berpikir terarah.. Strategi pengajaran membaca resiprokal merupakan strategi yang dikembangkan Palincsar dan Brown pada 1986. Langkah-langkah dalam strategi tersebut yang terdiri atas membuat prediksi, membuat pertanyaan, mengklarifikasi, dan meringkas dapat membantu siswa untuk meningkatkan pemahaman bacaan siswa (Stricklin, 2011:620). Strategi berpikir terarah merupakan strategi pembelajaran membaca yang meliputi kegiatan memprediksi, membaca, dan membuktikan prediksi. Wiesendanger (2001: 86) menyatakan bahwa strategi berpikir terarah dapat membantu siswa dalam mengembangkan pemahaman bacaan dan kemampuan berpikir kritis.

Kemampuan pemahaman bacaan siswa dapat diartikan sebagai kemampuan untuk memahami informasi yang disampaikan melalui sarana tulis (Nurgiyantoro, 2011: 371). Jadi, tes kemampuan pemahaman bacaan siswa dimaksudkan untuk mengukur pemahaman siswa terhadap isi teks, baik yang dinyatakan secara eksplisit maupun implisit. Taksonomi yang digunakan untuk mengukur kemampuan pemahaman bacaan siswa dalam penelitian ini, yakni taksonomi PISA 2015 yang terdiri atas akses dan pemerolehan informasi, integrasi dan interpretasi, serta refleksi dan evaluasi. Berikut merupakan penjabaran secara rinci mengenai tiga kategori tersebut (OECD, 2013: 22-24).

(1) Akses dan pemerolehan informasi (access and retrieve information). Tugas dalam kategori ini berupa menemukan detail informasi. Hal tersebut akan berguna bagi pembaca ketika ia mencari pekerjaan melalui iklan di surat kabar, mencari nomor telepon, dan menemukan sebuah fakta untuk mendukung atau menyangkal pendapat seseorang. Penilaian dalam kategori pemerolehan informasi berdasarkan infomasi yang disampaikan secara eksplisit di dalam teks. Siswa harus menemukan informasi berdasarkan syarat atau ciri-ciri yang disampaikan secara eksplisit dalam pertanyaan. Siswa harus mengidentifikasi satu atau beberapa elemen penting dari pertanyaan, seperti karakter, tempat atau waktu dan latar, serta mencocokkanya dengan teks.

Kegiatan pemerolehan informasi retrieving merupakan proses menyeleksi informasi yang diperlukan, sedangkan mengakses atau accessing merupakan proses menemukan lokasi dan keberadaan informasi yang diperlukan. Proses mengakases dan pemerolehan informasi melibatkan keterampilan yang berhubungan dengan menyeleksi, mengumpulkan, dan memperoleh informasi.

(2) Integrasi dan interpretasi. Integrasi dan interpretasi melibatkan proses memahami bacaan untuk memperoleh pemahaman secara mendalam terhadap teks. Integrasi memfokuskan pada pemahaman koherensi teks. Kegiatan integrasi menuntut siswa untuk menghubungkan beberapa informasi guna memperoleh makna. Siswa mengidentifikasi persamaan dan perbedaan, membuat perbandingan, atau memahami hubungan sebab dan akibat. Interpretasi merupakan proses membangun makna dari hal-hal yang disampaikan secara implisit. Pembaca harus mengenali hubungan yang tidak secara eksplisit disampaikan dan frasa atau kalimat konotasi.

Kegiatan menginterpretasi dan mengintegrasi melibatkan proses membangun sebuah penafsiran yang menuntut pembaca untuk memperluas kesan-kesan pertamanya terhadap teks yang dibacanya. Hal tersebut akan membuat pembaca memperoleh pemahaman secara lebih mendalam, spesifik, dan lengkap. Tugas-tugas yang dapat diberikan dalam kategori ini antara lain, membuat judul yang tepat sebuah teks, mengidentifikasi gagasan utama, menentukan tema teks, dan memaknai kata-kata atau frasa yang memberikan nuansa khusus dalam teks.

(3) Refleksi dan evaluasi. Kegiatan merefleksi dan mengevaluasi melibatkan pengetahuan dan ide-ide atau sikap di luar teks untuk dihubungkan dengan informasi yang terdapat di dalam teks. Selanjutnya, pembaca menghubungkan dengan konsep dan pengalaman yang dimilikinya. Kegiatan merefleksi menuntut pembaca untuk menggunakan 
pengalamannya guna membandingkan, membedakan, atau membuat hipotesis. Adapun kegiatan evaluasi menuntut pembaca untuk membuat penilaian di luar teks.

Merefleksi dan mengevaluasi isi teks menuntut pembaca untuk menghubungkan informasi di dalam teks dengan pengetahuan lain dari sumber-sumber lain. Pembaca juga harus menilai pendapat-pendapat di dalam teks yang berlawanan dengan pengetahuan pembaca. Oleh karena itu, pembaca harus mampu membangun pemahaman mengenai isi dan fokus teks. Penugasan yang dapat diberikan kepada siswa antara lain, mengidentifikasi informasi alternatif untuk menguatkan pendapat penulis atau mengevaluasi kecukupan bukti atau informasi yang terdapat di dalam teks.

Merefleksi dan mengevaluasi bentuk teks menuntut pembaca untuk mempertimbangkan secara objektif dan mengevaluasi kualitas dan ketepatan teks. Penugasan yang dapat diberikan dalam kategori ini antara lain, meminta siswa untuk menjelaskan atau mengomentari gaya atau style yang digunakan penulis dan mengidentifikasi tujuan serta sikap penulis.

Langkah-langkah pembelajaran pemahaman bacaan dengan menggunakan strategi pengajaran membaca resiprokal dapat dijelaskan sebagai berikut. (1) Guru membagi siswa menjadi kelompok-kelompok kecil beranggotakan 3 sampai 4 orang. (2) Guru mengawali pelajaran dengan memberikan apersepsi dan melakukan tanya jawab dengan siswa. (3) Guru membacakan sebuah judul teks di papan tulis dan meminta siswa untuk memprediksi isi teks tersebut. (4) Siswa dalam kelompoknya mengungkapkan prediksi isi teks. (5) Guru membagikan teks bacaan kepada masing-masing kelompok. (6) Siswa dalam kelompoknya membaca teks secara keseluruhan dalam hati. (7) Siswa dalam kelompoknya membuat pertanyaan-pertanyaan dan kunci jawaban berdasarkan isi bacaan. (8) Masing-masing kelompok mempresentasikan hasil diskusinya dengan cara menunjuk salah seorang anggota kelompoknya untuk menyampaikan pertanyaan yang telah dibuat. (9) Kelompok yang mendengarkan menjawab pertanyaan yang diberikan dari kelompok yang sedang presentasi. (10) Siswa dalam kelompoknya mengungkapkan jika ada kata-kata dan infor- masi-informasi yang sulit dipahami. (11) Siswa dalam kelompoknya membuat rangkuman dari teks. (12) Guru meminta salah seorang siswa untuk membacakan hasil ringkasan yang telah dibuatnya. (13) Kelompok yang mendengarkan memberikan komentar dan melengkapi hasil ringkasan yang disampaikan kelompok lain. (14) Guru memberikan apresiasi kepada kelompok-kelompok yang telah aktif dalam diskusi. (15) Guru melakukan evaluasi kegiatan pembelajaran.

Adapun langkah-langkah pembelajaran membaca dengan menggunakan strtaegi berpikir terarah dapat dijelaskan sebagai berikut. (1) Guru membagi siswa ke dalam kelompok-kelompok kecil beranggotakan 3 sampai 4 orang. (2) Guru membacakan atau menuliskan sebuah judul di papan tulis. (3) Siswa membuat prediksi berdasarkan judul tersebut. (4) Siswa menuliskan prediksinya pada lembar prediksi. (5) Guru mengarahkan siswa untuk membaca bagian pertama dari teks untuk memeriksa prediksi mereka. (6) Guru mengamati kinerja membaca mereka dan bantu siswa yang membutuhkan bantuan dengan kata-kata yang mungkin sulit dipahami. (7) Setelah siswa membaca bagian pertama, minta mereka menutup teks yang mereka baca. (8) Guru kembali mengajukan pertanyaan-pertanyaan berikut untuk memandu siswa mengevaluasi temuan dan prediksi baru mereka: apakah Anda benar, apa yang Anda pikirkan sekarang, dan menurut Anda apa yang akan terjadi? (9) Siswa mengisi lembar verifikasi prediksi dengan memberi tanda centang di bawah kategori lembar prediksi pada prediksi pertamanya. (10) Siswa melanjutkan kegiatan membaca pada bagian kedua. (11) Setelah siswa membaca bagian kedua, siswa menutup teks yang mereka baca. (12) Guru kembali mengajukan pertanyaan-pertanyaan berikut untuk memandu siswa: apakah Anda benar? Apa yang Anda pikirkan sekarang, dan menurut Anda apa yang akan terjadi? (13) Siswa kembali mengisi lembar verifikasi prediksi dengan memberi tanda centang di bawah kategori lembar prediksi pada prediksi ketiga dan menuliskan prediksinya kembali setelah membaca teks bagian kedua. (14) Mintalah siswa melanjutkan kegiatan membaca bagian lain. Pada setiap bagian bacaan, lanjutkan siklus memprediksi-membaca-mem- 
buktikan. (15) Guru melakukan evaluasi kegiatan pembelajaran.

Adapun tujuan penelitian adalah untuk (1) menguji keefektifan strategi pengajaran membaca resiprokal dibandingkan dengan strategi konvensional dalam pembelajaran pemahaman bacaan pada siswa kelas VIII SMP Negeri di Kabupaten Sleman, (2) menguji keefektifan strategi berpikir terarah dibandingkan dengan strategi konvensional dalam pembelajaran pemahaman bacaan pada siswa kelas VIII SMP Negeri di Kabupaten Sleman, (3) menguji strategi manakah yang paling efektif di antara strategi pengajaran membaca resiprokal, strategi berpikir terarah, dan strategi konvensional dalam pembelajaran pemahaman bacaan siswa kelas VIII SMP Negeri di Kabupaten Sleman, (4) mendeskripsikan pendapat guru mengenai kendala yang dihadapi dalam menerapkan strategi pengajaran membaca resiprokal dan berpikir terarah beserta solusi untuk mengatasi kendala tersebut.

\section{METODE}

Penelitian ini merupakan metode penelitian kombinasi dengan model penelitian sequential explanatory design. Metode penelitian kombinasi model sequential explanatory design adalah metode penelitian kombinasi yang menggabungkan metode penelitian kuantitatif dan penelitian kualitatif secara berurutan (Sugiyono, 2013: 415).

Tempat penelitian adalah di SMP Negeri 1 Mlati dan tempat uji instrumen di SMP Negeri 3 Mlati yang terletak di Kecamatan Tirtoadi, Kabupaten Sleman, Yogyakarta. Penelitian ini dilakukan pada semester genap tahun ajaran 2015/2016 pada bulan Maret sampai bulan April 2016.

Instrumen soal yang digunakan dalam penelitian ini berupa tes objektif berjumlah 30 butir soal prates dan 30 butir soal pascates. Instrumen dibuat berdasarkan pengembangan dari taksonomi PISA 2015 yang meliputi: akses dan pemerolehan informasi, integrasi dan interpretasi, serta refleksi dan evaluasi.

Rubrik observasi berisi rincian kegiatan pembelajaran dengan menggunakan strategi pengajaran membaca resiprokal dan strategi berpikir terarah di dalam kelas. Rubrik observasi tersebut juga berisi uraian mengenai kendalakendala yang terjadi dan solusi yang diberikan guru untuk mengatasi kendala selama selama proses pembelajaran dengan menggunakan kedua strategi tersebut.

Panduan wawancara berisi pertanyaan mengenai pendapat guru terhadap penerapan strategi membaca resiprokal dan strategi berpikir terarah. Selain itu, panduan wawancara juga berisi pertanyaan mengenai kendalakendala yang dihadapi guru dalam menerapkan strategi tersebut beserta solusi dalam mengatasi kendala.

\section{Teknik Analisis Data}

Teknik analisis data yang digunakan dalam penelitian ini adalah analisis varians satu jalan (anava) yang dilanjutkan dengan uji scheffe. Kriteria penerimaan dan penolakan hipotesis dalam penelitian ini menggunakan taraf signifikansi 0,05 atau $5 \%$. Seluruh proses perhitungan selengkapnya dibantu dalam program SPSS 20.

\section{HASIL DAN PEMBAHASAN}

Hasil uji normalitas dan uji homogenitas menunjukkan bahwa data yang diperoleh berdistribusi normal dan varians data bersifat homogen. Dengan demikian, uji anava untuk menguji hipotesis dapat dilakukan. Terdapat tiga hipotesis yang diuji pada penelitian ini. Berikut perincian ketiga uji hipotesis (1) strategi pengajaran membaca resiprokal lebih efektif dibandingkan dengan strategi konvensional dalam pembelajaran pemahaman bacaan, (2) strategi berpikir terarah lebih efektif dibandingkan dengan strategi konvensional dalam pembelajaran pemahaman bacaan, (3) strategi pengajaran membaca resiprokal paling efektif dibandingkan dengan strategi berpikir terarah dan strategi konvensional dalam pembelajaran pemahaman bacaan siswa kelas VIII SMP Negeri 1 Mlati.

Tabel 1 menunjukkan bahwa perhitungan uji scheffe pada kelompok kelompok eksperimen 1 dan kelompok kontrol diperoleh mean difference sebesar 3,333 dan signifikan dengan $p 0,000(p<0,05)$. Hasil uji scheffe tersebut tersebut menunjukkan bahwa strategi pengajaran membaca resiprokal lebih efektif 
Tabel 1. Hasil Uji Scheffe Pascates

\begin{tabular}{lccc}
\hline \multicolumn{1}{c}{ Kelompok } & & Mean Difference & $\boldsymbol{p}$ \\
\hline \multirow{2}{*}{ Kelompok Eksperimen 1 } & KK & 3,333 & 0,000 \\
& KE 2 & 1,633 & 0,044 \\
\hline \multirow{2}{*}{ Kelompok Eksperimen 2 } & KK & 1,700 & 0,034 \\
& KE 1 & 1,633 & 0,044 \\
\hline \multirow{2}{*}{ Kontrol } & KE 1 & 3,333 & 0,000 \\
& KE 2 & 1,700 & 0,034 \\
\hline
\end{tabular}

dibandingkan dengan strategi konvensional dalam pembelajaran pemahaman bacaan.

Hasil uji scheffe pada kelompok eksperimen 1 dan kelompok eksperimen 2 diperoleh mean difference sebesar 1,633 dan signifikan dengan $p 0,044(p<0,05)$. Hasil uji scheffe tersebut menunjukkan bahwa strategi pengajaran membaca resiprokal lebih efektif dibandingkan dengan strategi berpikir terarah dalam pembelajaran pemahaman bacaan.

Hasil uji scheffe pada kelompok eksperimen 2 dan kelompok kontrol diperoleh mean difference sebesar 1,700 dan signifikan dengan $\mathrm{p} 0,034(\mathrm{p}<0,05)$. Hasil uji scheffe tersebut tersebut menunjukkan bahwa strategi berpikir terarah lebih efektif dibandingkan dengan strategi konvensional dalam pembelajaran pemahaman bacaan. Jadi, berdasarkan hasil uji scheffe dapat diketahui bahwa pengajaran membaca resiprokal merupakan strategi yang paling efektif di antara ketiga strategi tersebut dengan urutan keefektifan, yakni strategi pengajaran membaca resiprokal, strategi berpikir terarah, dan strategi konvensional.

Keefektifan Strategi Pengajaran Membaca Resiprokal dalam Pembelajaran Pemahaman Bacaan

Tingkat keefektifan penggunaan strategi pengajaran membaca resiprokal dalam pembelajaran pemahaman bacaan dapat diketahui setelah kelompok eksperimen 1 mendapatkan perlakuan dengan menggunakan strategi pengajaran membaca resiprokal. Hasil analisis uji scheffe data pascates antara kelompok eksperimen 1 dan kelompok kontrol diperoleh mean difference sebesar 3,333 dan signifikan dengan $p 0,000(p<0,05)$.

Hasil uji scheffe tersebut menunjukkan bahwa terdapat perbedaan yang signifikan ke- mampuan pemahaman bacaan antara kelompok eksperimen 1 (strategi pengajaran membaca resiprokal) dengan kelompok kontrol (strategi konvensional). Strategi pengajaran membaca resiprokal lebih efektif digunakan dalam pembelajaran pemahaman bacaan karena strategi tersebut dapat membantu siswa dalam memahami bacaan secara mendalam. Hal ini senada dengan Moon (2011: 99) yang menyatakan bahwa strategi pengajaran membaca resiprokal merupakan sebuah strategi yang membantu siswa untuk memahami bacaan secara mendalam.

Langkah-langkah dalam strategi pengajaran membaca resiprokal yang terdiri atas kegiatan membuat prediksi, membuat pertanyaan, mengklarifikasi, dan meringkas dapat mendorong siswa untuk aktif dan kritis, sehingga pemahaman siswa dapat berkembang. Hasil penelitian ini selaras dengan penelitian Israel A. Sarasti (2007: 53) yang berjudul The effects of reciprocal teaching comprehension monitoring-strategy on 3rd grade students reading comprehension yang menyimpulkan bahwa strategi pengajaran membaca resiprokal efektif dalam meningkatkan kemampuan membaca siswa. Hasil penelitian kualitatif juga memperkuat hasil penelitian kuantitatif, yakni bahwa strategi pengajaran membaca resiprokal efektif diterapkan dalam pembelajaran pemahaman bacaan.

Strategi pengajaran membaca resiprokal memuat langkah-langkah yang mendorong siswa aktif, kritis, dan mandiri, sehingga dapat meningkatkan pemahaman siswa. Penerapan strategi pengajaran membaca resiprokal menuntut semua siswa untuk ambil bagian dalam pembelajaran melalui kegiatan memprediksi, membuat pertanyaan, mengklarifikasi, dan meringkas. Kondisi demikian menyebabkan pembelajaran membaca di kelas menjadi lebih aktif dan menyenangkan, 
sehingga pembelajaran yang terpusat pada siswa secara perlahan dapat terbentuk.

Kendala yang Dihadapi Guru beserta Solusi untuk Mengatasi Kendala

Penerapan strategi pengajaran membaca resiprokal tidak sepenuhnya berjalan lancar. Kendala pada tahap membuat prediksi, yakni sebagian besar siswa masih kesulitan dalam membuat prediksi isi teks, sehingga prediksi mereka masih belum tepat. Guru mengatasi siswa yang mengalami kesulitan membuat prediksi dengan cara memberikan arahan kepada siswa untuk memperbanyak kegiatan membaca.

Beberapa siswa masih takut dan ragu dalam menyampaikan prediksi mereka. Rasa takut dan ragu dalam diri siswa dapat diatasi dengan beberapa cara. Pertama, guru memberikan solusi dengan cara memotivasi siswa supaya berani berpendapat. Kedua, guru berupaya untuk mengendalikan kelas agar kebiasaan mengolokolok teman yang sedang memberikan pendapat dapat diminimalisir.

Kendala kedua pada tahap membuat pertanyaan, yakni sebagian besar siswa masih belum terampil dalam memilih hal-hal penting untuk digunakan dalam membuat pertanyaan. Guru mengatasi kendala pada tahap ini dengan cara memberikan contoh-contoh pertanyaan.

Kendala pada tahap mengklarifikasi, yakni ada beberapa siswa yang cenderung pasif dan takut untuk mengungkapkan hal-hal yang belum dipahami. Guru mengatasi kendala pada tahap mengklarifikasi dengan cara memberikan kesempatan kepada setiap kelompok untuk mendiskusikan hal-hal yang masih belum mereka pahami dari teks.

Kendala pada tahap kegiatan meringkas, yakni sebagian besar siswa hanya menulis ulang teks tanpa memilah informasi-informasi penting. Guru mengatasi kendala pada tahap meringkas dengan cara memberikan arahan cara meringkas yang tepat, yakni hanya memasukkan informasi-informasi yang penting dalam teks.

Berdasarkan hal-hal yang telah dipaparkan sebelumnya dapat disimpulkan bahwa dalam sebuah pembelajaran pemahaman bacaan diperlukan stategi pembelajaran yang dapat membantu siswa lebih mudah dalam memahami isi bacaan. Guru harus memilih strategi yang dapat mendorong siswa lebih aktif, mandiri, dan berpikir kritis dalam kegiatan pembelajaran, sehingga dapat meningkatkan pemahaman siswa terhadap bacaan. Strategi pengajaran membaca resiprokal dapat digunakan dalam pembelajaran pemahaman bacaan untuk mencapai tujuan pembelajaran yang optimal karena terbukti efektif untuk meningkatkan kemampuan pemahaman bacaan. Pembelajaran dengan menggunakan strategi konvensional terbukti kurang efektif karena kurang memfasilitasi siswa untuk aktif dalam pembelajaran, sehingga pemahaman bacaan siswa tidak berkembang.

Keefektifan Strategi Berpikir Terarah dalam Pembelajaran Pemahaman Bacaan

Tingkat keefektifan penggunaan strategi berpikir terarah dalam pembelajaran pemahaman bacaan dapat diketahui setelah kelompok eksperimen 2 mendapatkan perlakuan dengan menggunakan strategi berpikir terarah. Hasil analisis uji scheffe data pascates antara kelompok eksperimen 2 dan kelompok kontrol diperoleh mean difference sebesar 1,700 dan signifikan dengan $p 0,034(p<0,05)$.

Hasil uji scheffe tersebut tersebut menunjukkan bahwa terdapat perbedaan yang signifikan kemampuan pemahaman bacaan antara kelompok eksperimen 2 (strategi berpikir terarah) dengan kelompok kontrol (strategi konvensional). Strategi berpikir terarah lebih efektif digunakan dalam pembelajaran pemahaman bacaan karena strategi tersebut dapat membantu mengembangkan pemahaman siswa dan mendorong siswa untuk berpikir kritis. Hal tersebut selaras dengan Wiesendanger (2001: 86) yang mengemukakan bahwa strategi berpikir terarah dapat membantu siswa dalam mengembangkan pemahaman bacaan dan kemampuan berpikir kritis.

Pembelajaran pemahaman bacaan dengan menggunakan strategi berpikir terarah memfasilitasi siswa untuk menggunakan pengetahuan yang telah dimilikinya untuk memahami hal-hal baru. Haggard (1988: 531-532) mengemukakan bahwa strategi berpikir terarah memperlihatkan hubungan antara pengalaman dan penggunaan pengetahuan awal selama membaca. 
Hasil penelitian ini selaras dengan penelitian Yazdani \& Mohammadi (2015: 58) menyimpulkan bahwa penerapan strategi berpikir terarah meningkatkan pemahaman bacaan siswa karena kegiatan-kegiatan dalam strategi tersebut lebih interaktif dan memfasilitasi siswa dengan konsep baru, ide-ide, saran, dan cara berpikir. Hasil penelitian kualitatif juga memperkuat hasil penelitian kuantitatif, yakni bahwa strategi berpikir terarah efektif dalam meningkatkan pemahaman bacaan siswa. Tahap-tahap dalam strategi berpikir terarah memfasilitasi siswa untuk belajar secara aktif dan kritis dalam memahami bacaan. Selain itu, kegiatan memprediksi, membaca, dan membuktikan prediksi dilakukan tahap demi tahap, sehingga siswa memahami bacaan dengan lebih baik.

Kendala yang Dihadapi Guru beserta Solusi untuk Mengatasi Kendala

Penerapan strategi berpikir terarah tidak terlepas dari berbagai kendala. Kendala yang dialami guru sebagian besar terjadi pada awal penerapan strategi tersebut. Kendala pada tahap membuat prediksi, yakni sebagian besar siswa masih kesulitan membuat prediksi, sehingga prediksi mereka masih belum tepat. Guru mengatasi kesulitan membuat prediksi dengan cara memberikan stimulus pada siswa. Cara ini berguna untuk memunculkan ide-ide mengenai isi teks. Guru juga memberikan arahan kepada siswa untuk memperbanyak kegiatan membaca.

Kendala lain dalam tahap membuat prediksi, yakni siswa masih merasa takut dan malu dalam mengungkapkan prediksi, sehingga pemikiran mereka tidak berkembang. Adapula siswa yang masih pasif dan hanya mengandalkan teman lain untuk membuat prediksi. Guru mengatasi siswa yang masih takut dan malu dengan cara memotivasi dan meyakinkan siswa agar memiliki keberanian dalam berpendapat. Guru juga mengingatkan siswa untuk tidak saling mengejek pendapat dari teman yang lain. Solusi lain yang dapat diberikan guru, yakni dengan memberikan pujian dan semangat kepada siswa yang telah berani berpendapat. Hal tersebut penting untuk meningkatkan rasa percaya diri siswa.
Kendala pada tahap membaca sebenarnya tidak terlalu berarti, yakni hanya berupa kesalahan teknis. Siswa membaca teks yang diberikan guru secara keseluruhan. Padahal, siswa seharusnya melakukan kegiatan membuat prediksi, membaca, dan membuktikan prediksi secara bertahap pada tiap paragraf. Guru mengatasi kendala pada tahap membaca dengan mengingatkan kembali kepada siswa agar mengikuti instruksi yang telah disampaikan. Siswa diberi arahan agar membaca teks bagian demi bagian. Selain itu, guru perlu memantau agar siswa tidak membaca paragraf selanjutnya sebelum membuat prediksi.

Kendala pada tahap membuktikan prediksi hanya berupa kekeliruan yang dilakukan siswa dalam memberikan tanda cek pada lembar prediksi. Banyak siswa yang memberikan tanda cek lebih dari satu kolom. Selain itu, adapula siswa yang curang dengan mengganti jawaban mereka. Guru mengatasi kendala pada tahap membuktikan prediksi dengan cara mengingatkan siswa agar melaksanakan instruksi yang telah disampaikan.

Berdasarkan hal-hal yang telah dipaparkan sebelumnya dapat disimpulkan bahwa dalam sebuah pembelajaran pemahaman bacaan diperlukan stategi pembelajaran yang dapat membuat siswa aktif dan kritis dalam pembelajaran. Strategi berpikir terarah merupakan salah satu strategi yang dapat diterapkan dalam pembelajaran pemahaman bacaan untuk mencapai tujuan pembelajaran yang optimal. Strategi tersebut juga telah terbukti efektif untuk meningkatkan kemampuan pemahaman bacaan siswa. Pembelajaran dengan menggunakan strategi konvensional terbukti kurang efektif karena kurang memfasilitasi siswa untuk aktif dalam pembelajaran. Oleh karena itu, pemahaman siswa tidak berkembang karena siswa hanya pasif mengandalkan materi yang diberikan oleh guru.

Strategi yang Paling Efektif di antara Strategi Pengajaran Membaca Resiprokal, Strategi Berpikir Terarah, dan Strategi Konvensional dalam Pembelajaran Pemahaman Bacaan

Hasil analisis data membuktikan bahwa strategi pengajaran membaca resiprokal paling efektif dibandingkan strategi berpikir terarah 
dan strategi konvensional dalam meningkatkan pemahaman bacaan siswa. Tingkat keefektifan ketiga strategi dapat diketahui berdasarkan hasil uji scheffe dan perbedaan peningkatan skor rerata pada kelompok eksperimen 1, kelompok eksperimen 2, dan kelompok kontrol yang menunjukkan urutan keefektifan dimulai dari strategi pengajaran membaca resiprokal, strategi berpikir terarah, dan strategi konvensional.

Peningkatan skor rerata pada kelompok eksperimen 1 (strategi pengajaran membaca resiprokal) sebesar 3,57 dari 19,50 pada prates meningkat menjadi 23,07 pada pascates, peningkatan skor rerata pada kelompok eksperimen 2 (strategi berpikir terarah) sebesar 2,46 dari 18,97 pada prates meningkat menjadi 21,43 pada pascates, dan peningkatan skor rerata pada kelompok kontrol (strategi konvensional) sebesar 0,60 dari 19,13 pada prates meningkat menjadi 19,73 pada pascates. Perbedaan peningkatan skor rerata pada kelompok eksperimen 1 yang lebih besar daripada peningkatan skor rerata kelompok eksperimen 2 dan kelompok kontrol menunjukkan bahwa strategi pengajaran membaca resiprokal paling efektif diterapakan dalam pembelajaran pemahaman bacaan.

Hasil uji scheffe skor pascates kelompok eksperimen 1 (strategi pengajaran membaca resiprokal) dan kelompok eksperimen 2 (strategi berpikir terarah) diperoleh selisih rata-rata atau mean difference sebesar 1,633 dan signifikan dengan $p 0,044(p<0,05)$. Hasil ini membuktikan bahwa strategi pengajaran membaca resiprokal lebih efektif dibandingkan strategi berpikir terarah. Hasil uji scheffe skor pascates kelompok eksperimen 1 dengan kelompok kontrol diperoleh mean difference sebesar 3,333 dan signfikan dengan $p 0,000$ ( $p$ $<0,05)$. Hasil ini membuktikan bahwa strategi pengajaran membaca resiprokal lebih efektif dibandingkan strategi konvensional. Hasil uji scheffe skor pascates kelompok eksperimen 2 dengan kelompok kontrol diperoleh mean difference sebesar sebesar 1,700 dan signifikan dengan $p 0,034(p<0,05)$. Hasil ini membuktikan bahwa strategi berpikir terarah lebih efektif dibandingkan strategi konvensional.

Berdasarkan hasil uji scheffe terbukti bahwa strategi pengajaran membaca resiprokal paling efektif dalam meningkatkan pemahaman bacaan siswa dibandingkan dengan strategi berpikir terarah dan strategi konvensional. Strategi pengajaran membaca resiprokal memuat langkah-langkah yang tidak terdapat dalam kedua strategi tersebut, seperti membuat pertanyaan, mengklarifikasi, dan meringkas isi bacaan. Tahapan-tahapan tersebut berperan penting untuk membantu siswa meningkatkan kemampuan pemahaman bacaan siswa.

Kegiatan membuat pertanyaan bermanfaat bagi siswa dalam menentukan informasi-informasi penting dalam teks. Selain itu, kegiatan tersebut juga meminta siswa untuk memahami isi teks agar dapat membuat pertanyaan dengan tepat. Stricklin (2011: 621) memaparkan bahwa kegiatan membuat pertanyaan dapat meningkatkan pemahaman karena siswa harus mengerti apa yang telah dibaca untuk dapat membuat pertanyaan dengan baik.

Kegiatan mengklarifikasi sangat membantu siswa yang menemui kesulitan dalam teks. Biasanya, siswa menemukan kata-kata sulit dan tidak familiar, sehingga dapat mengganggu pemahaman siswa terhadap teks. Selain itu, siswa mungkin menemukan ide-ide penulis yang sulit dipahami. Kegiatan ini memfasilitasi siswa dan guru untuk aktif berdiskusi memecahkan berbagai permasalahan yang terjadi.

Kegiatan meringkas berkaitan erat dengan pemahaman siswa terhadap teks yang telah dibaca. Kissner (2006: xii) menyatakan bahwa kemampuan meringkas merupakan jantung dari pemahaman. Artinya, jika siswa mampu memahami teks dengan baik, maka siswa akan mampu membuat ringkasan dengan tepat. Kegiatan meringkas ini meminta siswa untuk aktif memahami bacaan dengan mengingat kembali isi teks dan menganalisis hal-hal penting yang mereka nyatakan dengan bahasa mereka sendiri. Kissner (2006: 5) mengemukakan bahwa kegiatan meringkas menuntut siswa untuk memahami dan menganalisis ide-ide. Oleh karena itu, kegiatan meringkas ini penting untuk diajarkan agar pemahaman siswa dapat meningkat.

Hasil penelitian ini mendukung hasil penelitian Mirriam Alfassi (1998) yang menyimpulkan bahwa strategi pengajaran membaca resiprokal lebih unggul dibandingkan dengan metode membaca tradisional dalam mengembangkan pemahaman bacaan. Hasil penelitian 
kualitatif juga memperkuat hasil penelitian kuantitatif, yakni bahwa strategi pengajaran membaca resiprokal lebih efektif dibandingkan dengan strategi berpikir terarah.

Hal demikian disebabkan strategi pengajaran membaca resiprokal memuat langkah membuat pertanyaan yang dapat melatih siswa berpikir kritis, sehingga pemahaman siswa dapat meningkat. Pembelajaran yang selama ini berlangsung kurang memfasilitasi siswa untuk mengembangkan pemahaman siswa. Siswa hanya pasif mengerjakan pertanyaan-pertanyaan dari guru. Akan tetapi, dalam strategi pengajaran membaca resiprokal siswa dituntut untuk dapat membuat pertanyaan dari teks yang mereka baca. Tahap inilah yang menjadikan strategi pengajaran membaca resiprokal lebih unggul dalam pembelajaran pemahaman bacaan.

Berdasarkan hal-hal yang telah dipaparkan sebelumnya dapat disimpulkan bahwa strategi pengajaran membaca resiprokal merupakan strategi yang paling efektif dalam meningkatkan pemahaman bacaan. Strategi pengajaran membaca resiprokal dapat mengantarkan siswa untuk memperoleh hasil pemahaman bacaan yang lebih optimal. Tahap membuat pertanyaan terbukti melatih siswa untuk meningkatkan daya kritis siswa, sehingga pemahaman mereka terhadap teks dapat berkembang. Tahap mengklarifikasi juga sangat membantu bagi siswa yang mengalami masalah dalam memahami bacaan. Terakhir, tahap meringkas dapat memperkuat pemahaman siswa terhadap isi teks.

\section{SIMPULAN}

Berdasarkan hasil analisis data dan pembahasan, maka dapat ditarik simpulan sebagai berikut. Pertama strategi pengajaran membaca resiprokal lebih efektif dibandingkan dengan strategi konvensional dalam pembelajaran pemahaman bacaan siswa kelas VIII SMP Negeri 1 Mlati. Langkah-langkah dalam strategi pengajaran membaca resiprokal terbukti dapat membuat siswa lebih aktif, kreatif, dan kritis dalam proses pembelajaran.

Kedua strategi berpikir terarah lebih efektif dibandingkan dengan strategi konvensional dalam pembelajaran pemahaman bacaan siswa kelas VIII SMP Negeri 1 Mlati. Langkahlangkah dalam strategi berpikir terarah terbukti dapat membuat siswa lebih aktif dan kreatif dalam proses pembelajaran.

Ketiga strategi pengajaran membaca resiprokal merupakan strategi yang paling efektif dibandingkan dengan strategi berpikir terarah dan strategi konvensional dalam pembelajaran pemahaman bacaan siswa kelas VIII SMP Negeri 1 Mlati. Langkah membuat pertanyaan, mengklarifikasi, dan meringkas isi bacaan yang terdapat dalam strategi pengajaran membaca resiprokal terbukti mampu mengantarkan siswa untuk memperoleh pemahaman bacaan yang lebih optimal.

Keempat kendala-kendala dalam penerapan strategi pengajaran membaca resiprokal di antaranya beberapa siswa masih kesulitan dalam membuat prediksi, membuat pertanyaan, mengklarifikasi, dan meringkas dengan tepat. Guru memberikan solusi dengan cara memotivasi, memberikan contoh, dan arahan kepada siswa.

Kelima kendala-kendala dalam penerapan strategi berpikir terarah di antaranya beberapa siswa masih kesulitan dalam membuat prediksi, kesalahan teknis dalam membaca, dan membuktikan prediksi. Guru memberikan solusi dengan cara memotivasi dan memberikan arahan kepada siswa.

\section{DAFTAR PUSTAKA}

Alfassi, Miriam. 1998. Reading for Meaning: The Efficacy of Reciprocal Teaching in Fostering Reading Comprehension in High School Students in Remedial Reading Classes. American Educational Research Journal, volume 35, II, hlm. 309-332.

Haggard, Martha R. 1988. Developing critical thinking with the directed readingthinking activity. ProQuest, volume 41, VI, hlm. 526-533.

Harris, Albert J. \& Sipay, Edward R. 1985. How to increase reading ability. New York: Longman Inc.

Kissner, Emily. 2006. Summarizing, paraphrasing, and retelling: skills for better reading, writing, and test tasking. Portsmouth: Heinemann.

Moon, Shannon S. 2011. Trying on reciprocal teaching: a novice's struggle becomes 
a veteran's success. ProQuest, volume 101, II, hlm. 97-100.

Nurgiyantoro, Burhan. 2011. Penilaian pembelajaran bahasa (Edisi Pertama). Yogyakarta: BPFE.

OECD. 2013. PISA 2012 results in focus. Diambil pada 15 Februari 2016 dari www. oecd.org.

OECD. 2013. PISA 2015 draft reading literacy framework. Diambil pada 15 Februari 2016 dari www.oecd.org.

Sarasti, Israel A. 2007. The effects of reciprocal comprehension-monitoring strategy on $3^{r d}$ grade students reading comprehension. Disertasi diterbitkan Proquest. University of North Texas.

Shanahan, Timothy. 2005. The national reading panel report: practical advice for teachers. Naperville: Learning Point Associates.
Smith, Frank. 1988. Understanding reading. Hillsdale: Lawrence Earlbaum Associates, Inc.

Stricklin, Kelley. 2011. Hands-on reciprocal teaching: a comprehension technique. ProQuest, volume 64, VIII, hlm. 620625.

Sugiyono. 2013. Metode penelitian kombinasi (mix methods). Bandung: Alfabeta.

Wiesendanger, Katherine D. 2001. Strategies for literacy education. Upper Saddle River: Merril Prentice Hall.

Yazdani, Mohammad Mehdi \& Mojtaba Mohammadi. 2015. The explicit instruction of reading strategies: directed reading thinking activity vs. guided reading strategies. International Journal of Applied Linguistics \& English Literature, volume 4, II, hlm. 53-60. 